\title{
New Perspectives on the Problems of the Exploitation Area and the Prehistoric Use of the Buda Hornstone in Hungary
}

\author{
Norbert Faragóa ${ }^{a}$, Réka Katalin Péter ${ }^{\mathrm{b}}$, Ferenc Cserpák ${ }^{\mathrm{c}}$, Dávid \\ Kraus $^{\mathrm{d}}$ and Zsolt Mester ${ }^{\mathrm{e}}$
}

\begin{abstract}
The mountainous areas of the Carpathian basin have provided a wide spectrum of siliceous rocks for prehistoric people. Although the presence of outcrops of a kind of chert, named Buda hornstone was already known by geological and petrographic investigations, the developing Hungarian petroarchaeological research did not pay much attention to this raw material. Its archaeological perspectives have been opened by a discovery made at the Denevér street in western part of Budapest in the 1980s. During the excavations of the flint mine, not much was known about the distribution of this raw material in the archaeological record. Since then the growing amount of archaeological evidences showed that its first significant occurrence in assemblages can be dated to the Late Copper Age Baden culture, and it became more abundant through the Early Bronze age Bell-Beaker culture until the Middle Bronze Age tell cultures. Until now, is outcrops of the Buda hornstone have been localised on the surface. Based on thin section examinations taken from two different outcrops, we have made a clear distinction between three variants. In the last few years, archaeological supervision has been conducted during house constructions, suggesting the Buda hornstone occurrence takes the form of a secondary autochthonous type of source. In the framework of our research program, a systematic check of the raw materials is planned in the lithic assemblages of the nearby prehistoric sites, as well as to look for extraction pits or other mining features with the application of geophysical methods and a thorough analysis of the surface morphology.
\end{abstract}

KEY-WORDS: Copper Age, Bronze Age, lithics, raw material, mining, chert, Hungary

To the memory of Veronika Gábori-Csánk and Miklós Gábori who unearthed the first extraction site of the Buda hornstone

a Institute of Archaeological Sciences Eötvös Loránd University Múzeum krt. 4/B, Io88 Budapest, Hungary; e-mail: norbert.farago@gmail.com; ORCID: 0000-0002-035I-I223

b Institute of Archaeological Sciences Eötvös Loránd University Múzeum krt. 4/B, I088 Budapest, Hungary; e-mail: preka9o@gmail.com; ORCID: oooo-ooo2-844I-8898

c Sárpatak u. 7. IV/I2, I048 Budapest, Hungary e-mail: cserpakfeca@gmail.com; ORCID: 0000-000I-5359-I498

d Budapest Historical Museum Aquincum Museum and Archaeological Park Szentendrei út I35, IO3I Budapest, Hungary; e-mail: krausdavid@gmail.com; ORCID: 00oo-ooo2-0006-9986

e Institute of Archaeological Sciences Eötvös Loránd University Múzeum krt. 4/B, Io88 Budapest, Hungary; e-mail: mester.zsolt@btk.elte.hu; ORCID: 00oo-oooI-5874-5935 
I68 Faragó et al

\section{INTRODUCTION}

There is a wide spectrum of siliceous rocks suitable for raw material of knapped stone tools for prehistoric people in the mountainous areas of the Carpathian basin (Biró 1988, 2008; Kaminská 200I, 2013; Rácz 20I3; Crandell 20I4). This richness is due to the complicated geological history of the Carpathians, developed in the Africa-Eurasia Collision Zone within the Alpine orogenesis (Földvary 1988; Plašienka et al., I997; Budai and Gyalog 2009; Mester et al., 2012). In connection with the orogenic folding of the Carpathians, strong volcanic activity took place in the Carpathian forelands from the middle of the Miocene onwards. As a consequence, a series of Tertiary volcanic formations lie in the inner part of the Carpathian arc from the Danube Bend (Visegrád Mountains, Hungary) through the mountain ranges of Northern Hungary and Southeastern Slovakia to the Vihorlat-Gutinian Ridge (Transcarpathian Ukraine) and the Oaş Mountains (Northern Romania; Harangi 200I; Karátson 2006; Harangi and Lenkey 2007). Mesozoic formations comprise mainly sedimentary siliceous rock types (e.g., radiolarite, chert, hornstone), while volcanic formations contain eruptive and metasomatic ones (e.g., obsidian, limnosilicites, silicified sandstone). This richness in siliceous rocks is reflected by prehistoric lithic assemblages in archaeological sites of the region (Dobosi 1978; Biró 1988, 1998a; Simán 1991).

The question of the identification of the raw materials of prehistoric knapped stone implements was hardly raised before the I980s. A general petrographic characterisation of the rock types occurring in the lithic assemblages was quite usual in the monographs about important Palaeolithic sites (Kadić 1916; Bartucz et al., 1940; Vértes 1964a; Gábori-Csánk 1968). Despite this, the problem of the origin of the raw materials was only rarely considered, mainly for specific and very characteristic rock types, such as the obsidian (Szabó I877), the Świeciechów (grey white-spotted) flint (Vértes 1960) or the quartz-porphyry (Vértes and Tóth 1963). Similarly, the problem of acquisition of lithic raw materials did not interest prehistorians in Hungary, although fortunate discoveries revealed the existence of prehistoric mining activities (Hillebrand 1929; Mészáros and Vértes 1955; Vértes 1964b; Fülöp 1973).

The situation changed from the 1980s onward; the geologist József Fülöp (1984) put the problem of mineral raw materials in a historical perspective. His initiative led to the linking of the geological, petrographical and archaeological problems of lithic raw materials to each other. Petroarchaeological research that began after this in Hungary had two foci: the identification of raw materials and the study of prehistoric mines (Biró ed. 1986, 1987). The first topic concerned the recognition and characterisation of siliceous rock types occurring on archaeological sites as well as the study of their distribution as a problem of circulation (Biró 1988, 1998a; Simán 1989; Bácskay 1990; Biró and Dobosi 199I; Biró et al., 2000). Related analytical approaches were applied to some particularly interesting raw materials: Carpathian obsidians, Transdanubian 

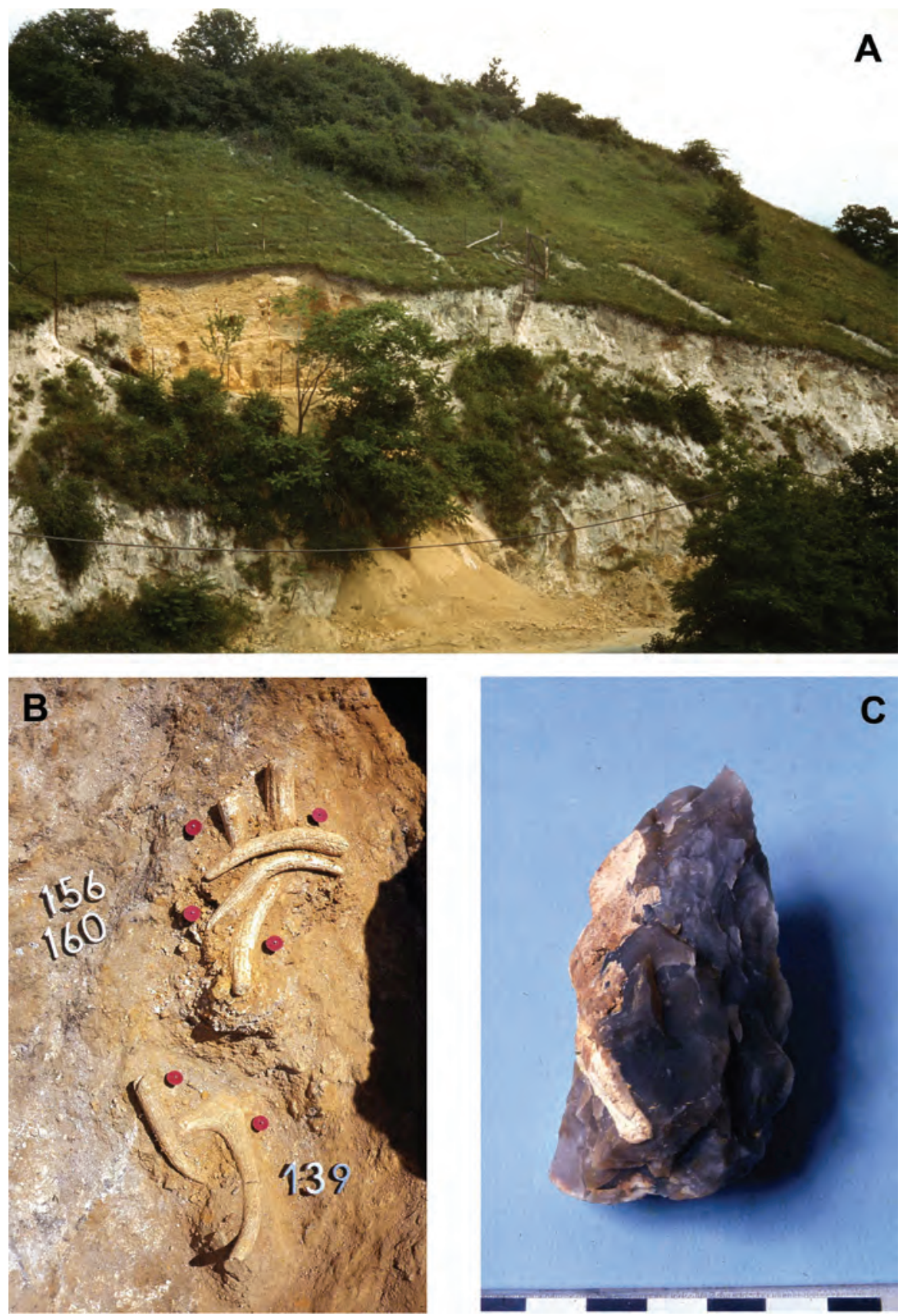

Fig. 1. Budapest-Farkasrét: A - view of the site; B - antler tools in level C; C - Mousterian-like sidescraper. Photos: M. Gábori. 
I70 Faragó et al

radiolarites and quartz-porphyry (Oddone et al., 1999; Markó et al., 2003; Kasztovszky and Biró 2006; Biró et al., 2009). The second topic was represented, on the one hand, by further investigations at already known mines and, on the other hand, by looking for new exploitation areas (Simán 1986, 1995a, 1995b; Biró and Regenye 1991; Bácskay I995a, 1995b, 1995c; Biró 1995; Ringer 2003; Biró et al., 20I0; Szolyák 20II; Tóth 20II). The research projects concentrated only on some kind of raw materials: the Transdanubian radiolarites, the Tevel flint, the quartz-porphyry and two specific limnosilicites. As a consequence, these investigations concerned mainly the Transdanubian Range and limited areas of the Bükk and Tokaj mountains.

\section{THE DISCOVERY AND EXCAVATIONS OF THE FLINT MINE AT BUDAPEST-FARKASRÉT}

Although the presence of outcrops of a specific kind of chert, named Buda hornstone, in the Buda Mountains was already known by geological and petrographical investigations (Károly 1936; Vadász 1960; Wein 1977; Juhász 1987), the developing Hungarian petroarchaeological research did not pay attention to this potential raw material. Its archaeological perspectives were opened by a fortuitous discovery made at the Denevér street next to the Farkasrét cemetery in the western part of Budapest (Vörös 1998-1999: 69; Biró 2002: 13I). A fragment of a mining tool made of antler and a few flint pieces were found and reported to the Hungarian Geological Institute. Since the pieces indicated an archaeological site, Veronika Gábori-Csánk from the Budapest Historical Museum started investigations to verify the discovery.

At the location where the antler tool fragment had been found, the Denevér street descends in a valley cut into dolomite (Fig. I:A). On the upper part of the northeastern slope of the valley, a reddish spot in the white dolomite was found to be an archaeological site (Gábori-Csánk 1988). Prospections by geoelectric method detected low-resistivity zones of possible extraction pits under the surface (Pattantyús-Á. I986; Pattantyús-Á. and Simon 1986).

The excavations of the Budapest-Farkasrét site were carried out in three campaigns in 1984, 1985 and 1987 with a $7 \mathrm{~m}$ large and $3.5 \mathrm{~m}$ long trench cut in the slope (GáboriCsánk 1988, 1989; Gábori-Csánk and Gábori 1995). Based on the morphology of the surface after excavations, the site was interpreted as a small valley which had been open during the Pleistocene but filled in before the Early Holocene. The infilling, composed by eroded slope sediments, chert detritus, pebble levels and soil lenses of torrential origin, had a complicated stratigraphy. However the archaeological material - consisting of mining tools made of antler, knapping waste of chert and hammerstones - have been found in three apparently undisturbed horizontal levels (Fig. I:B). At the bottom of the excavated area, two extraction pits were also observed (Gábori-Csánk and Gábori 

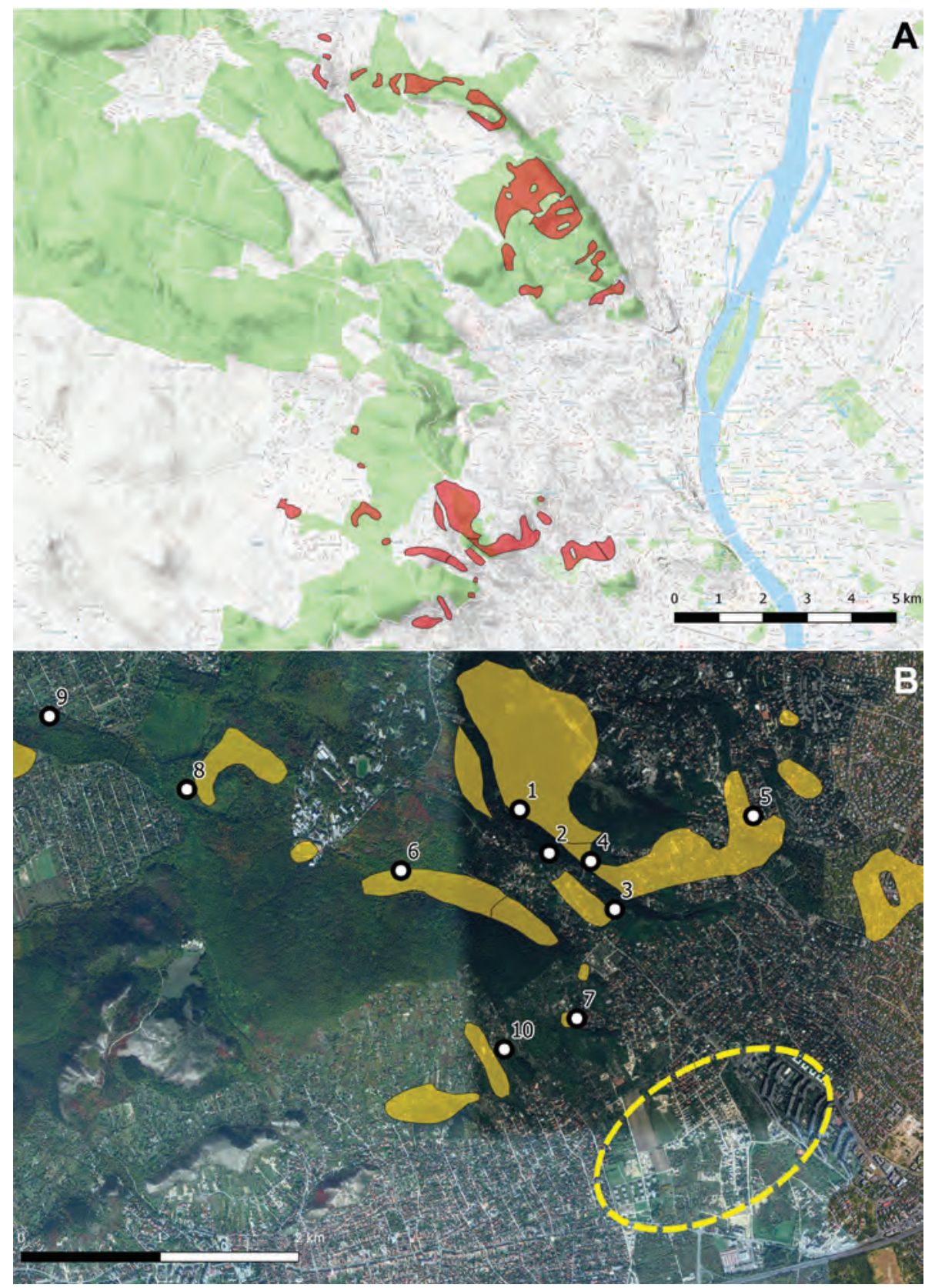

Fig. 2. Sources of the Buda hornstone: A - geological formations potentially containing siliceous rocks;

B - Site 1 to 10 and 'cherty dolomite' formations (ochre spots) in the southern zone, occurrences of Buda hornstone in the foothills (dashed line). Basic maps: GoogleMap, CAD: N. Faragó. 
I72 Faragó et al

1995). Of the 260 mining tools, 250 were made of red deer antler (Vörös 1998-1999, 2000). Besides nine truncated flakes and three retouched flakes, the only other lithic artefact was classified as a simple side scraper. It was considered as to be characteristic for the Mousterian (Gábori Csánk 1989: 19; Gábori-Csánk and Gábori 1995: 31).

The age of the mining activity at Budapest-Farkasrét site is very difficult to determine. Gábori-Csánk and Miklós Gábori (1995: 39-42) argued for a Middle Palaeolithic timeframe for the following reasons: I) the down cutting of the valley of the Denevér street dates to the Holocene, while the small valley of the site has to date to the Pleistocene; 2) there are no traces of blade production in the lithic material; 3 ) neither polishing nor shaft holes could be found on the antler tools; 4) not one fragment of pottery but a Mousterian side scraper was found in the lowest level (Fig. I:C). Two inconsistent radiocarbon dates have been obtained for the mine (Gábori-Csánk and Gábori 1995: 4I; Vörös 1998-I999: 96): 40,350 \pm 950 BP (GrN 15567) from charcoal found in the upper level and $3470 \pm 80 \mathrm{BP}$ (B 4709) from an antler without clear archaeological context. The first one corresponds more or less to the radiometric age of the Middle Palaeolithic Mousterian site of Érd (Gábori-Csánk 1968: 107), while the second one is younger than the dates of the flint mine of Sümeg exploited from the Middle Neolithic to the Middle Copper Age (Bácskay 1995a: 392).

\section{THE GEOLOGICAL CONTEXT OF THE BUDA HORNSTONE}

Gábori-Csánk and Gábori (1995) concentrated on the archaeological problems of the Budapest-Farkasrét flint mine. Despite this, sedimentological analysis of the stratigraphic sequence was not carried out. Concerning the origins of the sediments filling up the small valley, they cited published geological descriptions of the area. Neither the petrography nor the geological context of the extracted raw material was discussed.

According to Katalin T. Biró (2002: 13I), the outcrops of the Buda hornstone were visited several times in the course of the systematic raw material surveys in the I980s. The Lithotheca Comparative Raw Material Collection of the Hungarian National Museum has II samples of the Buda hornstone coming from seven localities (Biró and Dobosi I99I: I4-I5, II2, I23, I36-I37; Biró et al., 2000: 20, I5I). These localities represent geological occurrences of the formation named 'cherty dolomite' which dates to the Carnian stage of the Upper Triassic (Wein 1977: 17-19). According to recent geological nomenclature, this belongs to the Sashegy Dolomite Member of the Mátyáshegy Formation (Gyalog et al., 20I7). Sashegy Dolomite consists of grey dolomite formed in deep marine conditions. It contains grey or brownish-grey chert nodules and lenses, distributed parallel to the layers of the dolomite. In the Buda Mountains, it appears in the Irhás-árok-Sas-Hill zone and in the Hármashatár-Hill zone in the southern and 
northern part respectively (Fig. 2:A). In the northern part, chert nodules and layers also occur in the Mátyáshegy Limestone Member of the same formation (Gyalog et al., 20I7) but this material currently seems not to be of any archaeological importance. New palaeontological data suggest that some parts of the cherty dolomite in the southern zone could be dated to the Early and Middle Norian (Karádi et al., 2016). For evaluating the accessibility of the Buda hornstone, it is worth noting that nodules can also be found in the blocks of Upper Eocene breccia-conglomerates (for example, close to the Budapest-Farkasrét site in the southern zone; Fig. 3).

\section{BUDA HORNSTONE IN ARCHAEOLOGICAL ASSEMBLAGES}

During the excavation of the flint mine of Budapest-Farkasrét, not much was known about the distribution of this raw material in archaeological assemblages. Despite its relative early mineralogical-petrographical and geological definition in the literature (Károly 1936; Vadász 1960; Wein 1977; Juhász 1987), the real recognition of this material in archaeological assemblages came only at the beginning of the I99os. Certainly, the

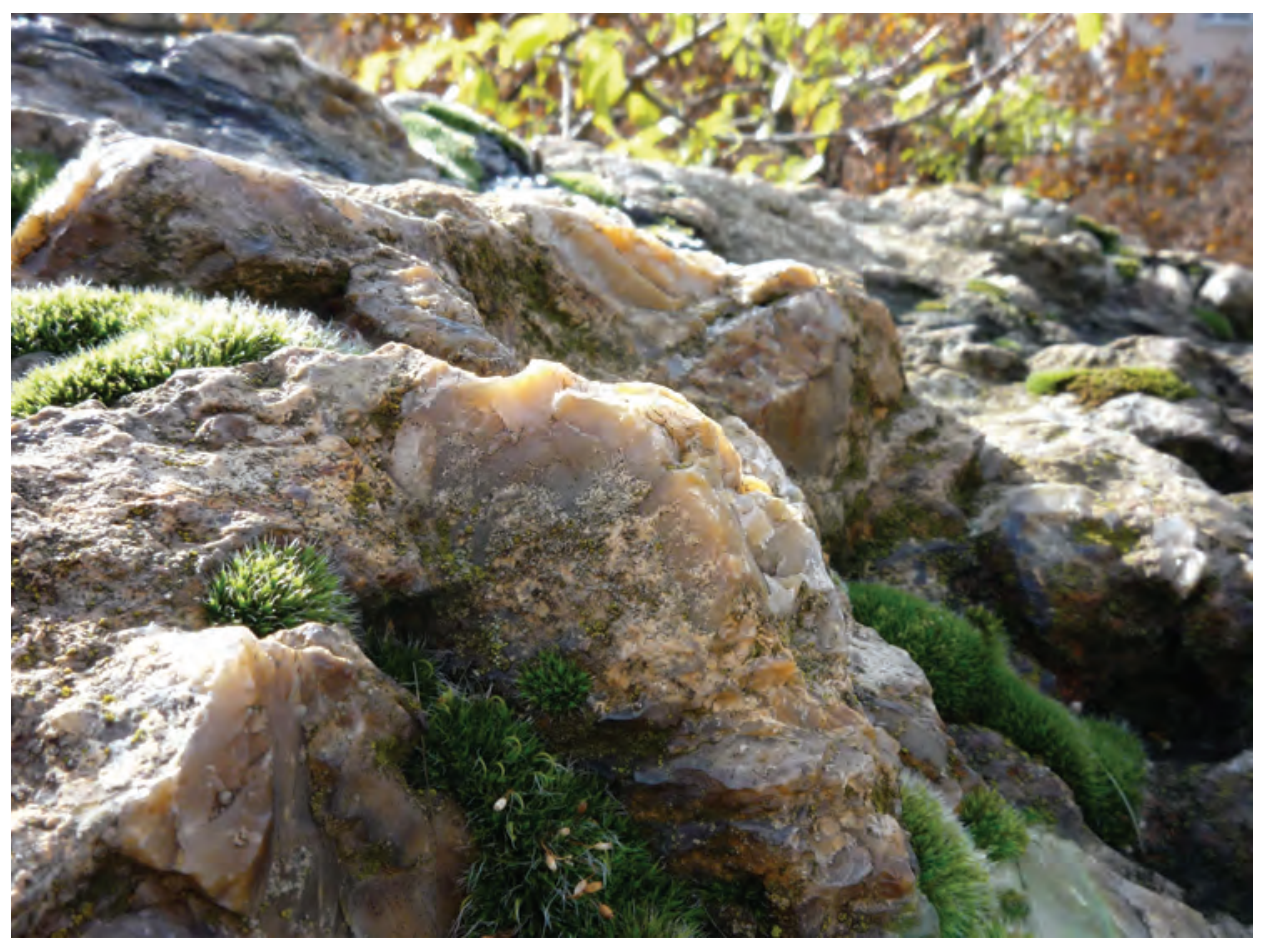

Fig. 3. Buda hornstone blocks in the brecciated formation at Site 5. Photo: N. Faragó. 
I74 $\mid$ Faragó et al

fact that this rock was extracted by prehistoric people drew the attention of archaeologists to the need to look for it among the raw materials in lithic assemblages.

Though the raw material of the majority (more than 80 percent) of the Early Bronze Age Bell-Beaker Culture assemblage of Budapest-Hollandi street is labelled 'Triassic hornstone', it is obvious from the paper of Biró (I99I) that it is the same rock type as we know nowadays as 'Buda hornstone'. However, according to the catalogue of the Lithotheca, she created this actual denomination in I988: samples 86/oI9, 86/020 and 86/O2I collected respectively at the Ördög-orom, Végvári-szikla and Irhás-árok (Budapest XII) localities were attributed to 'hornstone', while samples 88/oo6, 89/020 and 89/org from the same localities to 'Buda hornstone'.

Once this specific raw material had been clearly identified as Buda hornstone, it was reported from a couple of sites (Table I, Fig. 4). Éva Csongrádiné Balogh (I992) presented a lithic assemblage from the Szigetszentmiklós-Üdülősor site of the Bell-Beaker

Table 1. Occurrences of Buda hornstone on archaeological sites (see Fig. 4).

BA - Bronze Age; CA - Copper Age; EBA - Early Bronze Age; LCA - Late Copper Age; MBA - Middle Bronze Age; MP - Middle Palaeolithic

\begin{tabular}{|c|c|c|c|c|c|}
\hline No. & $\begin{array}{c}\text { Name of the } \\
\text { archaeological site }\end{array}$ & $\begin{array}{l}\text { District, } \\
\text { county }\end{array}$ & Age, culture & $\begin{array}{l}\text { Quantity, } \\
\text { proportion }\end{array}$ & Reference \\
\hline 1 & Bia-Öreghegy & Pest & MBA, Vatya & $>50 \%$ & $\begin{array}{l}\text { Csongrádiné Balogh } \\
\text { 1998; Horváth } 2009\end{array}$ \\
\hline 2 & Bölcske-Vörösgyír & Tolna & $\begin{array}{l}\text { EBA, Nagyrév, } \\
\text { MBA, Vatya }\end{array}$ & 5 of 28 pcs & Horváth et al., 2000a \\
\hline 3 & Budakalász & Pest & LCA, Baden & $\begin{array}{l}10 \text { of } 175 \\
\text { pcs }\end{array}$ & Balogh 2009 \\
\hline 3 & Budakalász & Pest & EBA, Bell-Beaker & $\begin{array}{l}80 \text { of } 86 \\
\text { pcs }\end{array}$ & Horváth 2017 \\
\hline 4 & Budapest-Albertfalva & Budapest XI & $\begin{array}{l}\text { EBA, Bell-Beaker; } \\
\text { CA, Furchenstich }\end{array}$ & $>80 \%$ & Biró 2002 \\
\hline 5 & Budapest-BEAC & Budapest XI & MBA, Vatya & & Horváth 2009 \\
\hline 6 & $\begin{array}{l}\text { Budapest-Csepel, II. } \\
\text { Rákóczi Ferenc street }\end{array}$ & Budapest XXI & EBA, Bell-Beaker & 39 pcs & Biró 2002 \\
\hline 7 & $\begin{array}{l}\text { Budapest-Hollandi } \\
\text { street }\end{array}$ & Budapest XXI & EBA, Bell-Beaker & $>80 \%$ & Biró 1991 \\
\hline 8 & $\begin{array}{l}\text { Budapest-Káposztás- } \\
\text { megyer }\end{array}$ & Budapest IV & LCA & $25 \%$ & Biró 1998b \\
\hline 9 & $\begin{array}{l}\text { Budapest-Medve } \\
\text { street }\end{array}$ & Budapest XXI & LCA & $35 \%$ & Biró 1998b \\
\hline 10 & $\begin{array}{l}\text { Budapest-Péteri } \\
\text { major }\end{array}$ & $\begin{array}{l}\text { Budapest } \\
\text { XXIII }\end{array}$ & MBA, Vatya & & Horváth 2009 \\
\hline 11 & Csongrád-Vidre & Csongrád & MBA, Vatya & & Horváth 2009 \\
\hline
\end{tabular}




\begin{tabular}{|c|c|c|c|c|c|}
\hline 12 & $\begin{array}{l}\text { Dunaújváros-Koszi- } \\
\text { derpadlás }\end{array}$ & Fejér & MBA, Vatya & & Horváth 2009 \\
\hline 13 & Érd(-Parkváros) & Pest & $\begin{array}{l}\text { MP, Quina type } \\
\text { Mousterian }\end{array}$ & $\begin{array}{l}19 \text { of } 810 \\
\text { pcs }\end{array}$ & Mester 2004 \\
\hline 14 & $\begin{array}{l}\text { Igar-Vámpuszta- } \\
\text { Galástya }\end{array}$ & Fejér & MBA, Vatya & & Horváth 2009 \\
\hline 15 & Kakucs-Balladomb & Pest & MBA, Vatya & & Horváth 2009 \\
\hline 16 & $\begin{array}{l}\text { Lovasberény-Mihá- } \\
\text { lyvár }\end{array}$ & Fejér & MBA, Vatya & & Horváth 2009 \\
\hline 17 & Mende-Leányvár & Pest & MBA, Vatya & & Horváth 2009 \\
\hline 18 & Nagykőrös-Földvár & Pest & MBA, Vatya & & Horváth 2009 \\
\hline 19 & Pákozd-Vár & Fejér & MBA, Vatya & & Horváth 2009 \\
\hline 20 & Páty-Nagyhegy & Pest & MBA, Vatya & & Horváth 2009 \\
\hline 21 & $\begin{array}{l}\text { Solymár-Mátyás- } \\
\text { domb }\end{array}$ & Pest & MBA, Vatya & & Horváth 2009 \\
\hline 22 & Soroksár-Várhegy & $\begin{array}{l}\text { Budapest } \\
\text { XXIII }\end{array}$ & MBA, Vatya & & Horváth 2009 \\
\hline 23 & $\begin{array}{l}\text { Százhalombatta-Sán- } \\
\text { chegy / Százhalom- } \\
\text { batta-Földvár }\end{array}$ & Pest & $\begin{array}{l}\text { EBA, Nagyrév, } \\
\text { MBA, Vatya }\end{array}$ & $90 \%$ & $\begin{array}{l}\text { Horváth et al., 2000b, } \\
\text { 2001; Pető et al., } \\
\text { 2002; Horváth } 2005\end{array}$ \\
\hline 24 & $\begin{array}{l}\text { Szigetszentmiklós- } \\
\text { Üdülősor }\end{array}$ & Pest & EBA, Bell-Beaker & $37.9 \%$ & $\begin{array}{l}\text { Csongrádiné Balogh } \\
1992\end{array}$ \\
\hline 25 & Tószeg & $\begin{array}{l}\text { Jász-Nagykun- } \\
\text { Szolnok }\end{array}$ & MBA & 1 of 55 pcs & $\begin{array}{l}\text { Csongrádiné Balogh } \\
\text { 1998, } 2001\end{array}$ \\
\hline 26 & Túrkeve-Terehalom & $\begin{array}{l}\text { Jász-Nagykun- } \\
\text { Szolnok }\end{array}$ & MBA, Ottomány & 4 of 10 pcs & $\begin{array}{l}\text { Csongrádiné Balogh } \\
\text { 2001; Horváth } 2009\end{array}$ \\
\hline
\end{tabular}

Culture, still in the close vicinity of Budapest and of the raw material sources of the Buda Mountains. The main raw material there (37.9\%) was also Buda hornstone completed by quartzite pebbles, several types of radiolarites and obsidian. She published a small part of the old collections of the Middle Bronze Age sites of Bia-Öreghegy and Tószeg (Csongrádiné Balogh 1998). Apart from the important information about the use-wear analysis concerning these 34 pieces, the raw materials were also identified: more than a half of the finds of Bia-Öreghegy are made on Buda hornstone, while only a single one of the five knapped stone artefacts from Tószeg was found to be of this material. From a later publication it became obvious that this latter piece is unique among the finds from that well known and iconic site near the Tisza River, because none of the newly published 50 pieces were made on Buda hornstone (Csongrádiné Balogh 200I). In this paper, another Bronze Age tell site was mentioned from the Great Hungarian Plain, Túrkeve-Terehalom, where four of the ten analysed pieces were made of a specific 'grey hornstone variant', without any precision concerning 
I76 Faragó et al

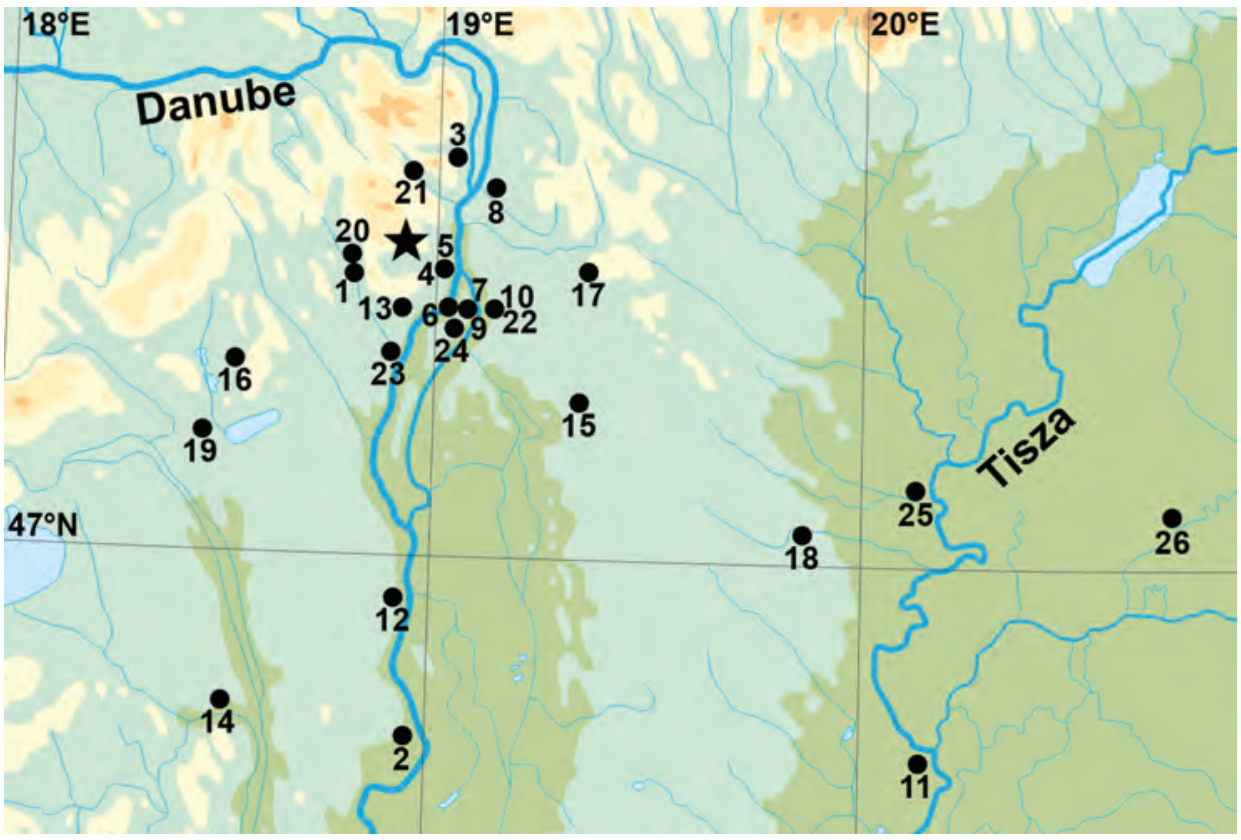

Fig. 4. The dots show the occurrence of Buda hornstone at prehistoric archaeological sites (see Table 1). The source is indicated by the star symbol. CAD: Zs. Mester.

their provenance but perhaps Buda hornstone too. From the Late Copper Age, the raw materials of both Budapest-Medve street and Budapest-Káposztásmegyer sites contained respectively 35 and 25 percent of Buda hornstone (Biró 1998b: Fig. 2). The famous cemetery of the Baden Culture at Budakalász was also mentioned in this article, but later a whole monograph was dedicated to this topic (Balogh 2009). According to the detailed analysis of the lithic assemblages found in the graves, most of the pieces could be attributed to local limnosilicite and distant radiolarite variants, and only less than Io pieces of the 175 were made of the specific hornstone from the Buda Mountains. In 2000, another distant occurrence of the Buda hornstone, dated to the Early-Middle Bronze Age, was reported from Bölcske-Vörösgyír, lying about $100 \mathrm{~km}$ south of the source area (Horváth et al., 2000a). Among the analysed 28 pieces, only 5 were made of Buda hornstone. Still in this paper, some references could be found to the raw material distribution of the lithic assemblage of the chronologically similar Százhalombatta-Sánchegy / Százhalombatta-Földvár sites. According to the author, 90 percent of the assemblage could be attributed to this raw material, which is not surprising, according to its close vicinity to Budapest. A later series of detailed studies were published about this very important site-complex and the lithic finds from the more 
New Perspectives on the Problems of the Exploitation Area and the Prehistoric Use $\mid \mathrm{I} 77$

recent excavation seasons, but the high ratio of the Buda hornstone remained the same among the large assemblage (Horváth et al., 200ob; Pető et al., 2002; Horváth 2005).

In 2002, a more comprehensive paper was published by Biró about the utilization of Buda hornstone, and new information was published about Bronze Age sites in the region of Budapest, the source of this raw material. The Budapest-Albertfalva site showed significant amount of lithic material from the Early Bronze Age BellBeaker Culture, and partly from the Copper Age Furchenstich culture. Among these assemblages, the Buda hornstone is dominant, comprising more than $80 \%$ of the finds (Biró 2002: 132). The author also mentioned the chronologically similar settlement and cemetery of Budapest-Csepel, II. Rákóczi Ferenc street. According to the preliminary information, 39 pieces of Buda hornstone accompanied by two broken pottery vessels were found in one single pit, which was interpreted as a symbolic grave. Due to the synthesis published by Tünde Horváth (2009), the list of the Buda hornstone occurrences from the Middle Bronze Age was completed with a series of sites: Pákozd-Vár, Kakucs-Balladomb, Igar-Vámpuszta-Galástya, Bia-Öreghegy, Budapest-BEAC, Dunaújváros-Kosziderpadlás, Lovasberény-Mihályvár, Mende-Leányvár, Nagykőrös-Földvár, Budapest-Péteri major, Soroksár-Várhegy, Solymár-Mátyásdomb, Csongrád-Vidre, Páty-Nagyhegy. The latest published information about an assemblage containing this raw material is from Budakalász, where an exceptionally large Bell-Beaker cemetery (Io70 graves!) and a contemporary settlement were unearthed (Horváth 2017). Among the 86 pieces from the cemetery, only 6 were made of lydite, radiolarite or limnoquartzite, while the rest were of Buda hornstone.

\section{NEW INSIGHTS ON THE USE OF BUDA HORNSTONE AS A PREHISTORIC RAW MATERIAL}

The growing amount of archaeological evidences demonstrates the importance of this raw material in the lithic economy of prehistoric communities in the region. Thus the question arose whether more extraction places existed in its source area. The ongoing research of the authors aims to clarify the mode of acquisition and management of the Buda hornstone in time and space. It attempts to look for traces of human activities near the outcrops and for occurrence of this raw material at archaeological sites, first of all in the region, as well as to study the procurement strategies and technical behaviour related to this rock type. Finally, this research is the result of the joining of three parallel interests. Dealing with the problems of raw material sources and inspired by the research at flint mines in Poland, two of us (Norbert Faragó and Zsolt Mester) are inspired to re-study the almost unpublished Budapest-Farkasrét site. Motivated by a fortuitous discovery, one of us (Ferenc Cserpák) has attempted to find more traces of prehistoric exploitation of the Buda hornstone. And finally one of us (Dávid Kraus), 
I78 Faragó et al
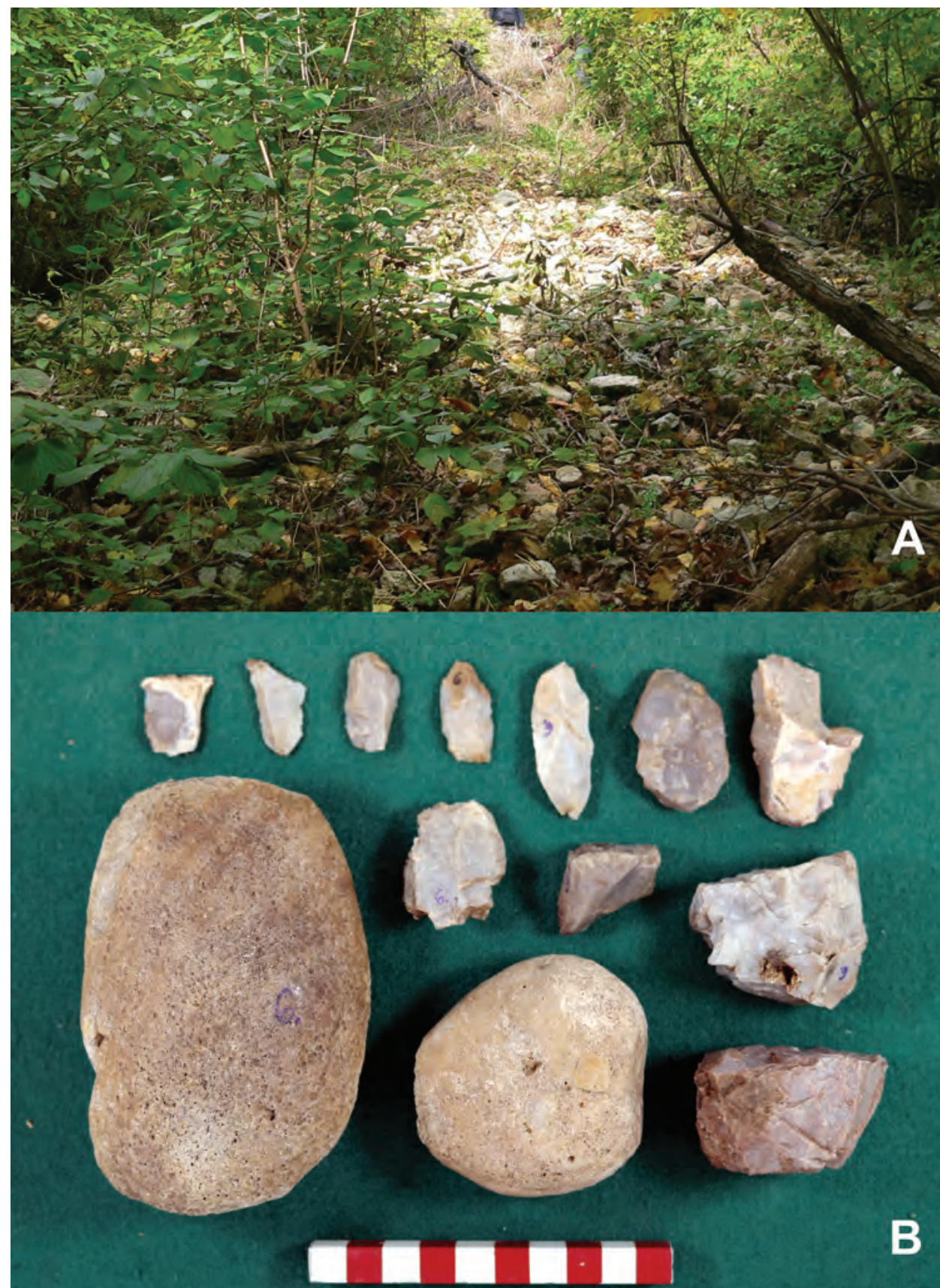

Fig. 5. Site 6 of the Buda hornstone: A - view of a stone accumulation; B - artefacts collected. Photos: F. Cserpák, N. Faragó. 
New Perspectives on the Problems of the Exploitation Area and the Prehistoric Use $\mid \mathrm{I} 79$

currently engaged in undertaking preventive excavations in the south-western part of Budapest is interested in clarifying contextual questions of the observed occurrences of this raw material close to prehistoric sites.

\section{Field surveys}

The first knapped artefacts of the Buda hornstone were found in Farkas valley near the Budapest-Farkasrét cemetery during an excursion in Autumn 2012. This unexpected discovery drew attention to this rock as a raw material. Based on information collected from archaeological and geological literature (Károly 1936; Dienes 1968; Wein 1977; Gábori-Csánk 1989; Csongrádiné Balogh 1992; Horváth et al., 2000a; Biró 2002; Horváth 2005, 2009) a field survey program was established. Systematic prospection was started in Spring 2013. Using the geological map published by György Wein (1977), occurrences of cherty dolomite were identified in the field in both northern and southern zones. Until Summer 2017, fifteen outcrops of the Buda hornstone had been localised. Up to now, only Outcrops I to 9 have yielded artefacts proving the prehistoric activities and which are considered as sites (Fig. 2:B). Outcrops Io to I5 still seem to be only geological sites. In most cases, the human activity on these sites comprises the presence of core remains and flakes without any ceramics. At Outcrop 6, however, hammerstones were also abundant (Fig. 5). The surface morphology at Outcrops 3, 6,8 and 9 suggests the possibility of the existence of extraction structures. Evidently, this requires further investigation. It is worth noting that the dolomite embedding the chert nodules is also varied: it is highly pulverised in the Farkas valley (Sites I, 2 and 4) and at Budapest-Farkasrét (Site 5), broken and friable at Ördög-orom (Site 3), and bedded at Végvári-szikla and Budakeszi-Kavics-árok (Sites 8 and 9).

\section{Petrography}

The chemical composition, mineralogical and petrographical definition of the Buda hornstone are less researched. Apart from Elemér Vadász (1960: 92) who studied it even in thin section (Biró and Dobosi 1991: I23; Biró 2002: I3I, footnote I), there is only an old paper of Erzsébet Károly (1936) that was dedicated to this topic. According to her data, the Buda hornstone, having silica content about 97\%, occurrs in limestone and dolomite. It is a minor component of the surrounding rocks, occurring as nodules, flat nodules, lenses and layers. The colour varies from light grey to dark grey, brownish and reddish variations, but greenish, purple shades can also appear.

Based on our macroscopic observations, the horn-like lustre is not necessarily a property of this rock which occurs in lustreless variations too. It has splinter and conchoidal fracture, flat-angled cracks also can be observed. In terms of homogeneity, veins and light spots in the material were also detected in several cases. The veins run irregularly in different directions, the light grey spots are separated by a blurred border, with no directional orientation. In some pieces, there are cavities, ranging from a few 
I80 $\mid$ Faragó et al

$\mathrm{mm}$ to $\mathrm{I}-\mathrm{I} .5 \mathrm{~cm}$, with quartz crystals inside. The cortex is whitish, light brownish, reddish, not homogeneous, rough and crumbly in many cases.

We observed several colour variants, it then emerged that they may differ in their chemical composition too. The purple colour appears along the veins and cracks in cloudy shape, possibly this is hematite, but further investigations are needed to verify this. The question arises whether it is possible to make differentiation according to colour variants. Three thin sections have been prepared from three different colour variants for investigation under the microscope. We selected a green and a red one from Site 6, and a grey one from Outcrop I2. It was soon discovered during the cutting that the green colour resulted from biological (plant) effect, the reason probably is that it was exposed on the surface for a long time. Each stone is tough, breaks along cracks and difficult to grind. The grey variant's texture is fine and full of spherical, cloudy nodules, some of them have blurred edge, other ones have sharper edges (Fig. 6: A and B). These nodules are about 0.I4 to $0.76 \mathrm{~mm}$ in size; many of them are silicified and contain some chalcedony. The texture is full of small particles at high magnification

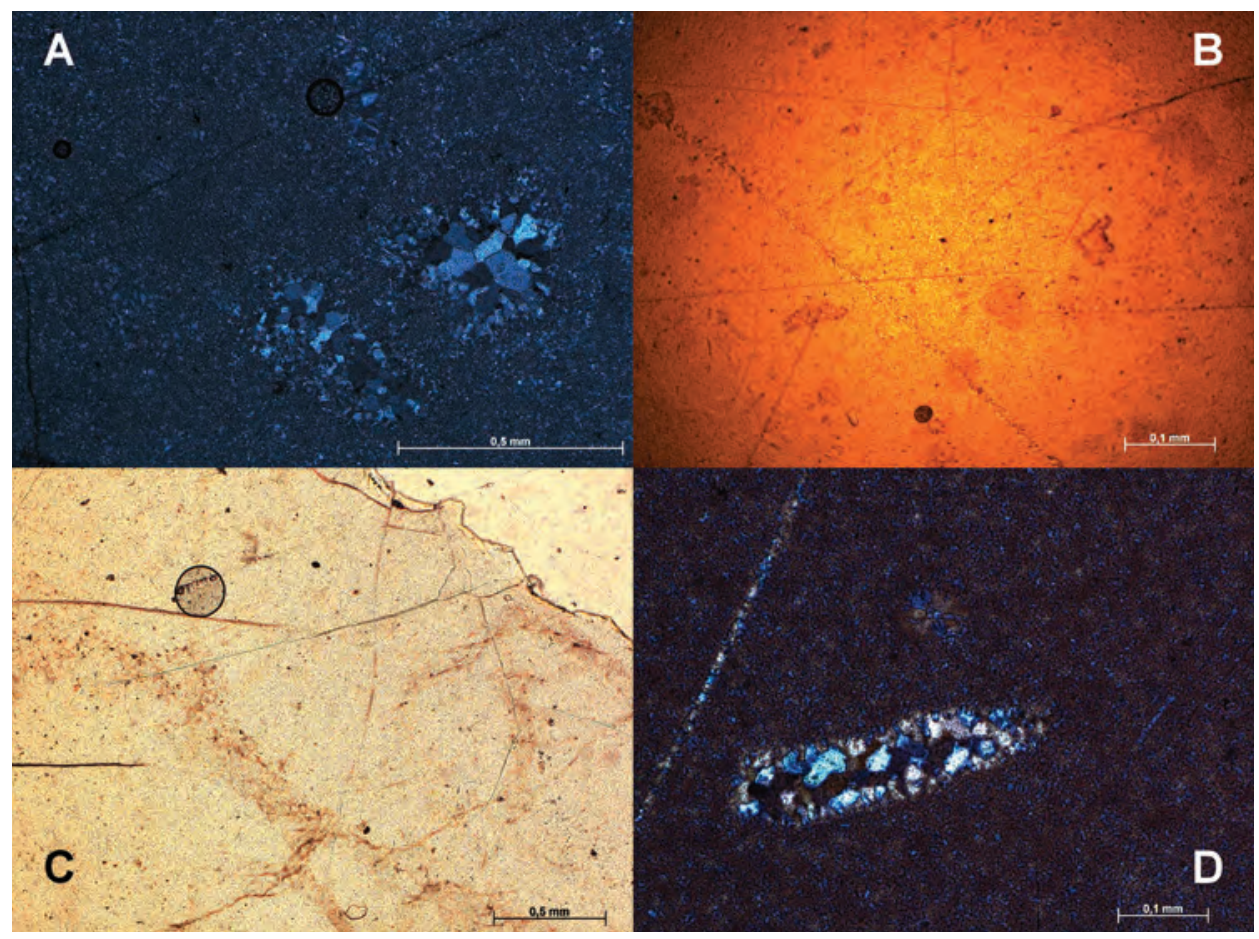

Fig. 6. Petrographic characteristics of Buda hornstone in thin sections: A - grey variant, circular fossil remains and nodule; $\mathrm{B}$ - grey variant, texture; $\mathrm{C}$ - red variant, circular fossil remains; $\mathrm{D}$ - red variant, nodule. Microphotos: R. K. Péter. 
New Perspectives on the Problems of the Exploitation Area and the Prehistoric Use $\mid$ I8I

and there are many cracks in it. Some nodules have chalcedony and quartzite. There are some circular fossil remains about $0.16 \mathrm{~mm}$ in diameter. Some remains can be suspected of being shells, one of them is subsequently silicified, and its size is about $0.2 \mathrm{Imm}$. The red variant's fabric is finer than the grey one, there are fewer nodules and it has some chalcedony too (Fig. 6: C and D). It is interesting that it has material filling the smaller interstices, and this is just visible in high magnification with crossed polarised light. There are some circular fossil remains, from 0.03 to $0.13 \mathrm{~mm}$ in diameter. An elongated fossil, $4.29 \mathrm{~mm}$ long and $0.32 \mathrm{~mm}$ wide, could be a sponge spicule. It has a few remains that could be shells, sized between 0.22 and $0.29 \mathrm{~mm}$. The green variant has fewer fine inclusions; the texture is dirtier, containing a little chalcedony and quartzite. It has I-2 nodules only; they are about $0.56 \mathrm{~mm}$ long and $0.1 \mathrm{~mm}$ wide. There are a few circular fossil remains; the biggest one is $0.38 \mathrm{~mm}$ in diameter.

Based on the thin section examinations, we made a clear distinction between the three samples, thus proving our basic idea that variants in colours differed also in internal properties. The grey one has a lot more nodules and it has the most fossils too, the red one has slightly less nodules and fossils and its texture is also different, lastly the green one differs greatly, it has a dirtier texture and nodules, fossils were hardly present in it. It is important to note that no conclusion can be drawn for the entire collection based only on these samples. However, these studies have justified the need for, and the importance of, further studies. Based on current field observations, different colour variants occur together, but it is still unclear whether variations based on colours would be suitable for identifying sources.

\section{Archaeology}

Although the primary autochthonous sources of the Buda hornstone could be limited to the extension of the above mentioned geological formations, other types of raw material sources need also to be taken into consideration when reconstructing prehistoric lithic procurement (Turq 2005; Mester et al., 2012). The identified Sites I to 9 are located at 250-300 m above sea level. From this area, foothills stretch out to the south, covered by Pleistocene slope sediments and loess-like sediments (Wein 1977) in which were cut stream valleys running from northwest to southeast. These circumstances suggest the Buda hornstone could have been obtained from a secondary autochthonous type of source.

In the last few years, archaeological supervision has been conducted during house constructions in the Spanyolrét, Madárhegy, Hosszúrét, Gazdagrét and Sasad quarters lying on this foothill between $\mathrm{I} 30$ and $195 \mathrm{~m}$ above sea level (Fig. 2:B). In the western part of this area, small (up to $5 \mathrm{~cm}$ ) patinated fragments of Buda hornstone came up in the uppermost (o to $40 \mathrm{~cm}$ ) soil level that can be interpreted as a result of erosional processes in the Holocene period. On the contrary, in the eastern part of the area, large quantities of bigger boulders (the size of a fist or child-head) have been unearthed from 
I82 $\mid$ Faragó et al
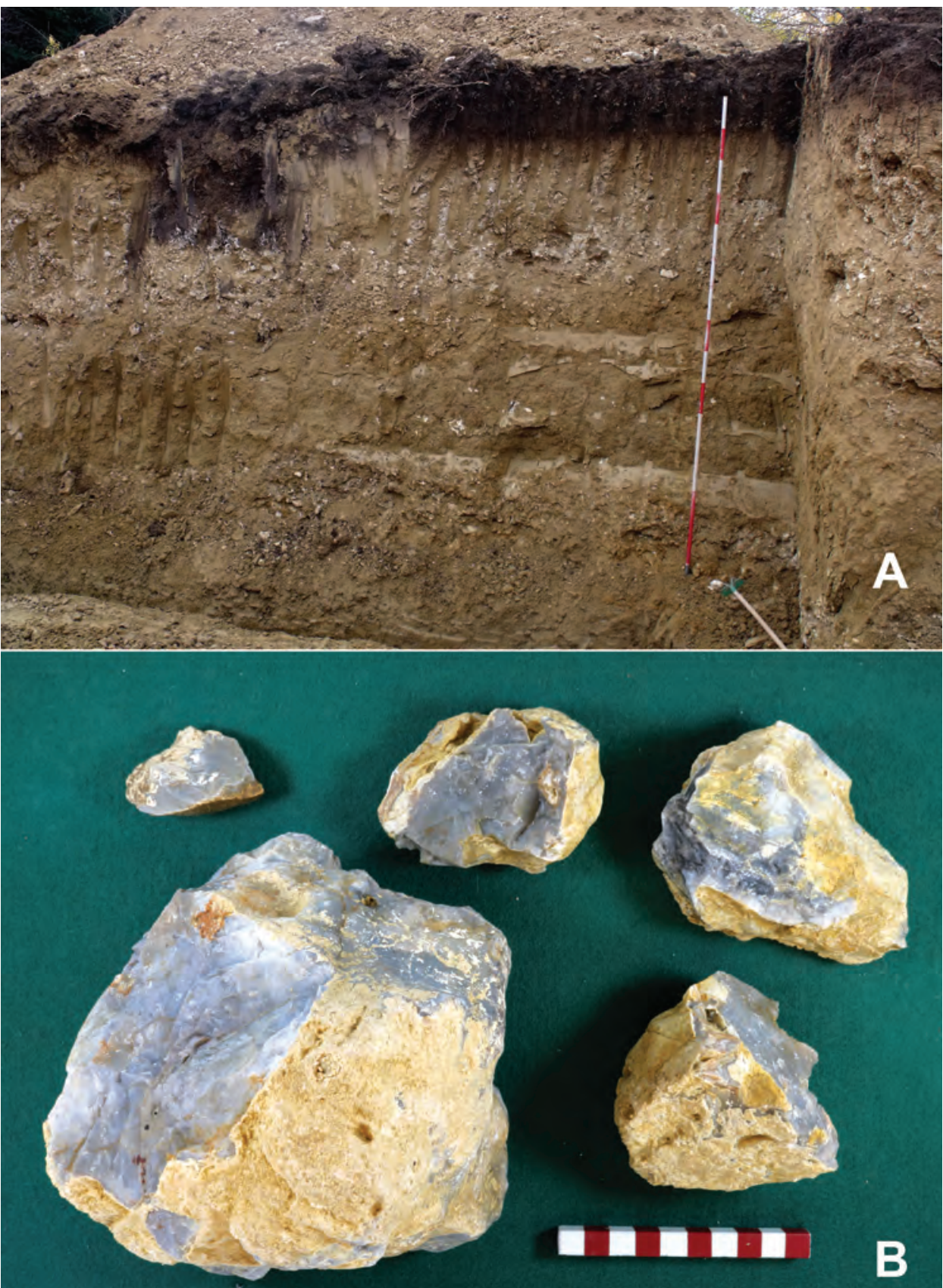

Fig. 7. Buried slope sediment with fragments of Buda hornstone in the foothill area (Nevegy köz, Budapest XI). A - profile of the site; B - Blocks collected at this locality. Photos: D. Kraus, N. Faragó. 
the clayey and loessic sediments below the Holocene soil (Fig. 7). It probably represents erosional accumulations from older (probably Pleistocene) periods. The most interesting observation was made at two archaeological sites where Buda hornstone fragments have been found in the excavation of a settlement of the Transdanubian Linear Pottery culture. However it is not clear yet whether Neolithic people used this raw material.

\section{CONCLUSIONS}

The existence of Upper Triassic chert in the Buda Mountains was demonstrated by geologists in the first half of the last century (Károly 1936). It occurs in the mountains in a northern and a southern zone (Wein 1977). Its use by prehistoric people was proven by the extraction site of Budapest-Farkasrét (in the southern zone). The excavations of the site between 1984 and 1987 yielded more than 200 mining tools, made almost exclusively of red deer antler, as well as hammerstones and a few retouched artefacts among the large quantity of lithic material recovered. The radiometric dating of the mine was ambiguous: one of the dates represents a Middle Palaeolithic age, the other one an early Middle Bronze Age. Initially, it was thought that the Palaeolithic age was thought to be reliable but without any archaeological evidence.

Since this raw material has been identified as Buda hornstone, it was recognised in the archaeological material of several prehistoric sites. Its significant occurrence firstly can be dated to the Late Copper Age Baden culture, and it became more abundant through the Early Bronze age Bell-Beaker culture until the Middle Bronze Age tell cultures, namely Nagyrév and Vatya horizons. The spatial distribution of this specific raw material is fairly limited, it is fond in assemblages from within a zone about $50-100 \mathrm{~km}$ around the original outcrops (Fig. 4). The characteristic tool types at most localities from the Bronze Age were bifacial tools, arrowheads, saw-like tools or scrapers, altogether this industry has a rather archaic aspect. The technology of the assemblages can be characterized mostly as a flake oriented one, which is due partly to the very poor quality of this raw material (Horváth 2005, 2009). In connection with the nature of the material, some scholars suggest the possibility of deliberate utilization of fire both during the mining of the blocks and/or during the preparation of the blanks (Biró 2002; Horváth 2005). Recently, this topic has been a subject of a detailed analysis of a specific limnosilicite as well as of quartz-porphyry (metarhyolite) from the Bükk Mountains. This concluded that either obtaining or production techniques involving intense heat would need a more complicated technology, and thus the study of this question requires a more elaborate research background (Tóth 2016).

Concerning the archaeological evidence for the older dating of the BudapestFarkasrét site, the lithic assemblage of the Middle Palaeolithic site of Érd where the Buda hornstone would have played an important role beside the dominant quartzite 
I84 Faragó et al

is often cited (Biró 1991: 94, 1998b: 160, 2002: 131; Horváth 2009: 42I). They refer to the study of István Dienes (1968) who undertook an analysis of the raw materials of the site. Here it should be noted that in fact, neither Dienes nor Gábori-Csánk mention that any raw material of Érd had originated from the Buda Mountains. Dienes (I968: III) gave only a global attribution for all the raw materials $(23.8 \%$ in total) different from quartzite. Based on analogous rock types known from the mountains, he attributed sedimentary rocks with yellow and brown colour to the Jurassic, while those with grey and black colour to the Triassic. He was convinced that all these types could be collected by the prehistoric inhabitants from the nearby gravels of Helvetian (i.e. Burdigalian) age. The mistake concerning the importance of the Buda hornstone in the assemblage of Érd is probably due to the misunderstanding of the table presenting the raw material composition of the industry by tool types following the determinations of Dienes (Gábori-Csánk 1968: 174). There are hornstone ('silex corné' - I27 pcs), Triassic chert ('silex triasique' - 5 pcs), and Jurassic chert ('silex jurassique' - I pc.) on the list. It is clear that these names refer to general rock types, rather than specific varieties. An analysis carried out by one of us has confirmed that in fact the Buda hornstone really is present in the assemblage (Mester 2004: 236). In total I29 artefacts were attributed to more than six macroscopically different chert types. Among them ig belong to a type similar to the Buda hornstone obtained from the Budapest-Farkasrét extraction site. So it seems hardly likely that the Neanderthals of Érd had invested a lot of energy in mining for such a small amount of raw material. Consequently, it has to be stated here, despite the conclusion made by Gábori-Csánk the Palaeolithic age of the BudapestFarkasrét mine cannot be supported by the material from the site at Érd.

Similarly, the data referring to the Buda industry from the Lower Palaeolithic period are wrong too (Biró 199I: 94, 1998b: 160; Horváth 2009: 42I). In this case also the mistake is based on the appearance of the 'hornstone' in the publication of László Vértes (1965: 104) as one of the raw materials of the pebbles found together with Middle Pleistocene fauna at the caves of the Castle-Hill of Buda. Vértes, however, showed that these finds were not artefacts.

In the framework of the ongoing research program, a systematic check of the raw materials in the lithic assemblages of prehistoric sites unearthed in the region of Budapest is planned. It will clarify if Buda hornstone were used by prehistoric knappers in other periods too. In a wider perspective, it is an important and fascinating question whether prehistoric groups had similar or different strategies for the procurement and management of Buda hornstone according to periods or cultural units. The analysis of the technical behaviour will provide further data for studying these issues.

Our first results obtained during field surveys are very promising in order to identify more extraction sites. To look for extraction pits or other mining features the application of geophysical methods and a thorough analysis of the surface morphology are required. Similarly, the geomorphological context of the Budapest-Farkasrét site 
New Perspectives on the Problems of the Exploitation Area and the Prehistoric Use $\mid$ I85

needs to be understood. Thus new geoarchaeological investigations are required. The evaluation of the recently recognised occurrences in the foothill area as a potential raw material source is also crucial for a better reconstruction of procurement strategies (cf. Fernandes et al., 2008). For the same reason, the petrographic characterisation of the variants have to be continued.

\section{ACKNOWLEDGEMENTS}

We are grateful to colleagues from the Prehistoric and Migration period Department of the Budapest Historical Museum, and especially to Gábor Szilas and Farkas Márton Tóth for supporting our research program. Réka Katalin Péter is indebted to Sándor Józsa from the Institute of Geography and Earth Sciences of Eötvös Loránd University, Budapest for his help in preparing and analysing the thin sections. The observations under a microscope ZEISS AXIO Scope. Ar were made at the Laboratory of Archeometry of the Institute of Archaeological Sciences of the Eötvös Loránd University, Budapest, which was equipped thanks to the project 'KMOP-4.2.I/B-IO-2OII-0002: Interdisciplinary, innovative research directions and the development of the infrastructural background of industrial cooperation as well as the introduction of new educational technologies at ELTE'.

\section{REFERENCES}

Bácskay, E. 1990. New investigations into the processing and distribution of flint from the SümegMogyorósdomb flint mine in Hungary. In M.-R. Séronie-Vivien and M. Lenoir (eds), Le silex de sa genèse à l'outil. Actes du VE Colloque international sur le Silex, Bordeaux, I7 sept.-2 oct. I987., 239-249. Paris, Cahiers du Quaternaire 17.

Bácskay, E. 1995a. H2. Sümeg-Mogyorósdomb, Veszprém country. Archaeologia Polona 33: 383-395.

Bácskay, E. 1995b. H5. Erdöbénye-Sáspatak, Borsod country. Archaeologia Polona 33: 395-400.

Bácskay, E. I995c. H9. Hárskút-Édesvízmajor, Veszprém country. Archaeologia Polona 33: 408-409.

Balogh, É.Cs. 2009. The lithic finds from Budakalász. In M. Bondár and P. Raczky (eds), The Copper age cemetery of Budakalász, 379-407. Budapest.

Bartucz, L., Dancza, J., Hollendonner, F., Kadić, O., Mottl, M., Pataki, V., Pálosi, E., Szabó, J. and Vendl, A. 1940. Die Mussolini-Höhle (Subalyuk) bei Cserépfalu. Budapest, GeologicaHungarica, Series Palaeontologica I4.

Biró, K.T. (ed.) 1986. Papers for the Ist International Conference on Prehistoric Flint Mining and Lithic Raw Material Identification in the Carpathian Basin, Budapest-Sümeg 1986, vol. I. Budapest.

Biró, K.T. (ed.) 1987. Papers for the Ist International Conference on Prehistoric Flint Mining and Lithic Raw Material Identification in the Carpathian Basin, Budapest-Sümeg 1986, vol. 2. Budapest.

Biró, K.T. 1988. Distribution of lithic raw materials on Prehistoric sites: an interim report. Acta Archaeologica Academiae Scientiarum Hungaricae 40: 25I-274.

Biró, K.T. 1991. Bell-Beaker culture lithic implements from Hungary. Acta Archaeologica Carpathica 30 : $87-96$. 
I86 Faragó et al

Biró, K.T. 1995. H8. Szentgál-Tüzköveshegy, Veszprém country. Archaeologia Polona 33: 402-408.

Biró, K.T. 1998a. Lithic implements and the circulation of raw materials in the Great Hungarian Plain during the Late Neolithic Period. Budapest.

Biró, K.T. 1998b. Limits and connections. In M. Németh (ed.), The Roman town in the modern city, Proceedings of the International Colloquium held on the occasion of the Iooth anniversary of the Aquincum Museum 1994 Budapest, I52-157. Budapest, Aquincum Nostrum 2.

Biró, K.T. 2002. New data on the utilization of Buda hornstone in the Early Bronze Age. Budapest Régiségei 36: I3I-I43.

Biró, K.T. 2008. Köeszköz-nyersanyagok Magyarország területén. A Miskolci Egyetem Közleménye A sorozat, Bányászat 74: II-37.

Biró, K.T. and Dobosi, V.T. 1991. Lithotheca - Comparative Raw Material Collection of the Hungarian National Museum. Budapest.

Biró, K.T. and Regenye, J. 199I. Prehistoric Workshop at Szentgál-Tüzköves. Acta Archaeologia Hungaricae I8: 337-375.

Biró, K.T., Dobosi, V.T. and Schléder, Zs. 20oo. Lithotheca II - The Comparative Raw Material Collection of the Hungarian National Museum, Vol. II. Budapest.

Biró, K.T., Szilágyi V. and Kasztovszky, Zs. 2009. Új adatok a Kárpát-medence régészeti radiolarit forrásainak ismeretéhez. Archeometriai Mühely 6(3): 25-44.

Biró, K.T., Regenye, J., Puszta, S. and Thamóné Bozsó, E. 20Io. Preliminary report on the excavations of the Nagytevel flint mine. Archaeologiai Értesitó I35(I): 5-25.

Budai, T. and Gyalog, L. (eds) 2009. Geological map of Hungary for tourists - I:200 000. Budapest.

Crandell, O. 20I4. Knappable lithic resources of North-Western Romania: A mineralogical study. Journal of Lithic Studies I (I): 73-84.

Csongrádiné Balogh, É. 1992. Szigetszentmiklós-Üdülősor kora bronzkori telepének kőeszköz vizsgálata. In P. Havassy and L. Selmeczi (eds), Régészeti kutatások az Mo autópálya nyomvonalán I., 2OI-2II. Budapest. BTM Mühely 5 .

Csongrádiné Balogh, É. 1998. Tipológiai és traszeológiai vizsgálatok rézkori és bronzkori pattintott kőeszközökön. Folia Archaeologica 47: 13-4I.

Csongrádiné Balogh, É. 200I. Adatok a rézkori, bronzkori pattintott kőeszközök tipológiai értékeléséhez (Jász-Nagykun-Szolnok megye). Tisicum I2: 9I-I06.

Dienes, I. 1968. Examen pétrographique de l'industrie. In V. Gábori-Csánk, La station du Paléolithique moyen d'Érd-Hongrie, III-II4. Budapest, Monumenta historica Budapestinensia 3.

Dobosi, V.T. 1978. A pattintott kőeszközök nyersanyagáról (Über das Rohmaterial der retuschierten Steingeräte). Folia Archaeologica 29: 7-19.

Fernandes, P., Raynal, J.-P. and Moncel, M.-H. 2008, Middle Palaeolithic raw material gathering territories and human mobility in the southern Massif Central, France: first results from a petroarchaeological study on flint. Journal of Archaeological Science 35: 2357-2370.

Földvary, G.Z. 1988. Geology of the Carpathian Region. Singapore-Teaneck.

Fülöp, J. 1973. Funde des prähistorischen Silexgrubenbaues am Kálvária-Hügel von Tata. Acta Archaeologica Academiae Scientiarum Hungaricae 25: 3-25.

Fülöp, J. 1984. Az ásványi nyersanyagok története Magyarországon. Budapest.

Gábori-Csánk, V. 1968. La station du Paléolithique moyen d'Érd - Hongrie. Budapest, Monumenta historica Budapestinensia 3.

Gábori-Csánk, V. 1988. Une mine de silex paléolithique à Budapest, Hongrie. In H.L. Dibble and A. Montet-White (eds), Upper Pleistocene prehistory of Western Eurasia, I4I-I43. Philadelphia, University Museum Monograph 54.

Gábori Csánk, V. 1989. Európa legrégibb bányászati emléke Farkasréten. Magyar Tudomány 34(I): I3-2I. 
Gábori-Csánk, V. and Gábori, M. 1995. Öskori kovafejtö Budapest-Farkasréten. Budapest, unpublished manuscript.

Gyalog, L., Maros, Gy. and Pelikán, P. (eds) 2017. Budapest geokalauza. Budapest Geoguide. Budapest.

Harangi, Sz. 20or. Neogene to Quaternary Volcanism of the Carpathian-Pannonian Region - a review. Acta Geologica Hungarica 44: 233-258.

Harangi, S. and Lenkey, L. 2007. Genesis of the Neogene to Quaternary volcanism in the Carpathian-Pannonian region: Role of subduction, extension, and mantle plume. In L. Beccaluva, G. Bianchini and M. Wilson (eds), Cenozoic Volcanism in the Mediterranean Area, 67-92. Boulder, Geological Society of America Special Paper 418.

Hillebrand, J. 1929. Neuere Ausgrabungen auf dem Avasberg bei Miskolcz in Ungarn. Eiszeit und Urgeschichte 6: I36-I4I.

Horváth, T. 2005. Stone finds from excavation seasons 1998, 1999, 2000 and 200I. Techno-typological analysis. In I. Poroszlai and M. Vicze (eds.), Százhalombatta Archaeological Expedition SAX Annual Report 2, I35-I55. Százhalombatta.

Horváth, T. 2009. Pattintással készült eszközök kronológiai szerepe a kora- és középső bronzkor folyamán. Tisicum 19: 4I3-440.

Horváth, T. 20I7. The stone implements and wrist-guards of the Bell Beaker cemetery of Budakalász (Mo/I2). Vjesnik Arheoloskog Muzeja u Zagrebu 50: 7I-II8.

Horváth, T., Kozák, M. and Pető, A. 20ooa. Újabb adatok a középső bronzkor kőiparához: BölcskeVörösgyír bronzkori tell-település kőanyagának komplex (petrográfiai, régészeti) feldolgozása. Komárom-Esztergom Megyei Önkormányzat Múzeumainak Közleményei 7: 187-235.

Horváth, T., Kozák, M. and Pető, A. 20oob. Complex analysis of stone industry on the SzázhalombattaFöldvár (Early and Middle Bronze Age). In I. Poroszlai and M. Vicze (eds), Százhalombatta Archaeological Expedition SAX Annual Report I, IO3-II9. Százhalombatta.

Juhász, Á. 1987. Évmilliók emlékei. Magyarország földtörténete és ásványkincsei. 2nd edition. Budapest.

Kadić, O. 1916. Ergebnisse der Erforschung der Szeletahöhle. Mitteilungen aus dem Jabrbuche der königlichen Ungarischen Geologischen Reichsanstalt 23: I6I-30I.

Kaminská, L. 200I. Die Nutzung von Steinrohmaterialien im Paläolithikum der Slowakei. Quartär 5I/52: $8 \mathrm{I}-\mathrm{IO} 6$.

Kaminská, L. 20I3. Sources of raw materials and their use in the Palaeolithic of Slovakia. In Zs. Mester (ed.), The lithic raw material sources and interregional human contacts in the Northern Carpathian regions, 99-I09. Kraków-Budapest.

Karádi, V., Pelikán, P. and Haas, J. 20I6. A Budai-hegység felső-triász medence kifejlődésű dolomitjainak conodonta biosztratigráfiája. Földtani Közlöny I46(4): 37I-386.

Karátson, G. 2006. Aspects of Quaternary relief evolution of Miocene volcanic areas in Hungary: A review. Acta Geologica Hungarica 49: 285-309.

Károly, E. 1936. Szarukövek a Budai hegységben (Notes sur les cherts de dolomites et calcaires se trouvant dans les montagnes de Buda). Földtani Közlöny 66(IO-I2): 254-277.

Kasztovszky, Zs. and Biró, K.T. 2006. Fingerprinting Carpathian obsidians by PGAA: first results on geological and archaeological specimens. In 34th International Symposium on Archaeometry, 3-7 May 2004 Zaragoza, Spain, 30I-308. Zaragoza.

Markó, A., Biró, K.T. and Kasztovszky, Zs. 2003. Szeletian felsitic porphyry: non-destructive analysis of a classical Palaeolithic raw material. Acta Archaeologica Academiae Scientiarum Hungaricae 54: 297-314.

Mester, Zs. 2004. La production lithique à la station d'Érd (Hongrie). In É. Fülöp and J. Cseh (eds), Die aktuellen Fragen des Mittelpaläolithikums in Mitteleuropa - Topical issues of the research of Middle Palaeolithic period in Central Europe, 233-250. Tata, Tudományos Füzetek I2. 
I88 Faragó et al

Mester, Zs., Faragó, N. and Lengyel, Gy. 20I2. The lithic raw material sources and interregional human contacts in the northern Carpathian regions: A research program. Anthropologie 50 (3): 275-293.

Mészáros, Gy. and Vértes, L. 1955. A paint mine from the Early Upper Palaeolithic age near Lovas (Hungary, County Veszprém). Acta Archaeologica Academiae Scientiarum Hungaricae 5: I-32.

Oddone, M., Márton, P., Bigazzi, G. and Biró, K.T. 1999. Chemical characterisations of Carpathian obsidian sources by instrumental and epithermal neutron activation analysis. Journal of Radioanalytical and Nuclear Chemistry 240(I): I47-I53.

Pattantyús-Á., M. 1986. Geophysical results in archaeology in Hungary. Geophysics 5I (3): 56I-567.

Pattantyús-Á., M. and Simon, A. 1986. Prospecting of prehistoric flint-quarries by geoelectric method. In K.T. Biró (ed.), Papers for the Ist International Conference on Prehistoric Flint Mining and Lithic Raw Material Identification in the Carpathian Basin, Budapest-Sümeg I986, vol. I, I23-I29. Budapest.

Pető, A., Kozák, M., Horvát, T. and Kovács-Pálffy, P. 2002. Examination of the stone implements of a Bronze Age earthwork in Hungary. In E. Jerem and K.T. Biró (eds), Archaeometry 98, Proceedings of the $3 I^{\text {tt }}$ Symposium, Budapest, April 26-May 3 1998. Vol. II, 783-791. Oxford, British Archaeological Reports, International Series I043 (II). Archaeolingua Central European Series I.

Plašienka, D., Grecula, P., Putiš, M., Kováč, M. and Hovorka, D. 1997. Evolution and structure of the Western Carpathians: an overview. In P. Grecula, D. Hovorka and M. Putiš (eds), Geological evolution of the Western Carpathians, I-24. Bratislava, Mineralia Slovaca - Monograph.

Rácz, B. 2013. Main raw materials of the Palaeolithic in Transcarpathian Ukraine: geological and petographical overview. In Zs. Mester (ed.), The lithic raw material sources and interregional human contacts in the Northern Carpathian regions, I3I-I46. Kraków-Budapest.

Ringer, Á. 2003. Öskőkori kovabányászat és kovakő-feldolgozás a miskolci Avason (Des mines et des ateliers de silex préhistoriques sur le mont Avas à Miskolc). Herman Ottó Múzeum Évkönyve 42: 5-15.

Simán, K. 1986. Limnic quartzite mines in Northeast-Hungary. In K.T. Biró (ed.), Papers for the Ist International Conference on Prehistoric Flint Mining and Lithic Raw Material Identification in the Carpathian Basin, Budapest-Sümeg 1986, vol. I, 95-99. Budapest.

Simán, K. 1989. Northern flint in the Hungarian Palaeolithic. In J.K. Kozlowski (ed.), „Northern”(Erratic and Jurassic) flint of South Polish origin in the Upper Palaeolithic of Central Europe, 87-94. Kraków.

Simán, K. I99I. Patterns of raw material use in the Middle Paleolithic of Hungary. In A. Montet-White and S. Holen (eds), Raw material economies among Prehistoric hunter-gatherers, 49-57. Lawrence, Publications in Anthropology 19.

Simán, K. 1995a. H4. The Korlát-Ravaszlyuktető workshop site in North-Eastern Hungary. Archaeologia Polona 33: 4I-58.

Simán, K. 1995b. Hi. Prehistoric mine on the Avas Hill at Miskolc. Archaeologia Polona 33: 37I-382.

Szabó, J. 1877. Lobsidienne préhistorique en Hongrie et en Grèce. In F.-F. Rómer (ed.), Congrès International d'Anthropologie et d'Archéologie Préhistoriques, Compte-rendu de la huitième session à Budapest I876, Premier volume, 96-100. Budapest.

Szolyák, P. 20II. Elsődleges nyersanyag-feldolgozás nyomai a szeletai kvarcporfír lelőhelyén (Bükkszentlászló). Herman Ottó Múzeum Évkönyve 50: 47-66.

Tóth, Z.H., 2oIr. Újabb adalék a szeletai üveges kvarcporfír előforduláshoz: Bükkszentlászló, Hideg-víz. Gesta (Miskolc) I0: I47-I49.

Tóth, Z.H. 20I6. Paleolithic heat treating in Northeastern Hungary? An archaeometric examination of the possible use of fire-setting in Stone Age quarries in the Bükk area. Archaeologia Polona 54: I29-I36.

Turq, A. 2005. Réflexions méthodologiques sur les études de matières premières lithiques. Paléo I7: III-I32. Vadász, E. 1960. Magyarország földtana. Budapest.

Vértes, L. 1960. Aus Polen stammendes Silexmaterial im ungarischen Paläolithikum und Mesolithikum. Ein Beitragzur Archäologie der Karpathen. Acta Archaeologica Carpathica I: 167-I72. 
Vértes, L. (ed.) 1964a. Tata. Eine mittelpaläolithische Travertin-Siedlung in Ungarn. Budapest, Archaeologia Hungarica 43.

Vértes, L. I964b. Eine prähistorische Silexgrube am Mogyorós-domb bei Sümeg. Acta Archaeologica Academiae Scientiarum Hungaricae 16: 187-215.

Vértes, L. 1965. Az öskökor és az átmeneti kökor emlékei Magyarországon. Budapest, A Magyar Régészet Kézikönyve I.

Vértes, L. and Tóth, L. 1963. Der Gebrauch des glasigen Quarzporphyrs im Paläolithikum des BükkGebirges. Acta Archaeologica Academiae Scientiarum Hungaricae I5: 3-IO.

Vörös, I. 1998-1999. Antlers from the Prehistoric flint mine at Denevér street (Budapest - Farkasrét). Folia Archaeologica 47: 69-IO2.

Vörös, I. 2000. Antler remains from the Prehistoric flint mine of Denevér street (Farkasrét, Budapest). In Zs. Mester and Á. Ringer (eds), A la recherche de l'Homme Préhistorique. Volume commémoratif de Miklós Gábori et de Veronika Gábori-Csánk, 2000, II7-I2I. Liège, E.R.A.U.L. 95.

Wein, Gy. 1977. A Budai hegység tektonikája. Budapest. 
